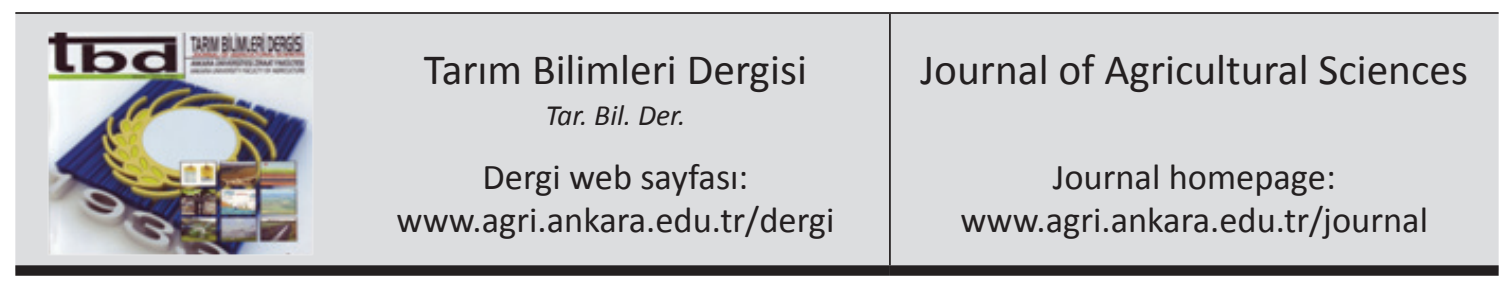

\title{
Effect of Supplementation with Green and Black Tea on Microbiological Characteristics, Antimicrobial and Antioxidant Activities of Drinking Yoghurt
}

\author{
Gülfem ÜNAL ${ }^{a}$, Cem KARAGÖZLÜ ${ }^{a}$, Özer KINIK ${ }^{a}$, Ecem AKAN ${ }^{b}$, Ayşe Sibel AKALIN ${ }^{a}$ \\ ${ }^{a_{E}}$ ge University, Faculty of Agriculture, Department of Dairy Technology, 35100, Bornova, Izmir, TURKEY \\ ${ }^{\boldsymbol{b}}$ Adnan Menderes University, Faculty of Agriculture, Department of Dairy Technology, Aydin, TURKEY
}

\section{ARTICLE INFO}

Research Article DOI: 10.15832 ankutbd.446430

Corresponding Author: Gülfem ÜNAL, E-mail: gulfem.unal@ege.edu.tr, Tel: +90 (232) 3112732

Received: 10 March 2016, Received in Revised Form: 26 October 2016, Accepted: 26 October 2016

\begin{abstract}
The influence of supplementation with green and black tea on microbiological properties, antimicrobial and antioxidant activities of drinking yoghurt were investigated during 21 days of storage. The samples supplemented with $2 \%$ either green or black tea had higher viable counts of both yoghurt starter bacteria than those of infused by the ratio of $4 \%$. Both green and black tea extracts showed antimicrobial activity on E. coli, B. cereus, S. aureus and C. albicans however this effect was detected higher in samples containing green tea. The samples added green tea extract had the highest DPPH scavenging activity when compared to those supplemented with black tea extract throughout the storage. Green tea had a superior effect than black tea in terms of total phenolic content of drinking yoghurt samples.
\end{abstract}

Keywords: Tea; Drinking yoghurt; Antimicrobial; Antioxidant; Viability

\section{Yeşil ve Siyah Çay İlavesinin İçilebilir Yoğurdun Mikrobiyolojik Özellikleri ile Antimikrobiyal ve Antioksidan Aktivitesi Üzerine Etkisi}

\section{ESER BILGISII}

Araştırma Makalesi

Sorumlu Yazar: Gülfem ÜNAL, E-posta: gulfem.unal@ege.edu.tr, Tel: +90 (232) 3112732

Geliş Tarihi: 10 Mart 2016, Düzeltmelerin Gelişi: 26 Ekim 2016, Kabul: 26 Ekim 2016

\section{ÖZET}

Yeşil ve siyah çay ilavesinin içilebilir yoğurdun mikrobiyolojik özellikleri ile antimikrobiyal ve antioksidan aktiviteleri üzerine etkisi 21 günlük depolama boyunca araştırılmıştır. \% 2 yeşil veya siyah çay ilave edilen örneklerde canlı yoğurt starter bakteri sayısı \% 4 oranında çay ilave edilen örneklere göre daha yüksek bulunmuştur. Gerek yeşil gerekse siyah çay ekstraktı E. coli, B. cereus, S. aureus and C. albicans üzerinde antimikrobiyal aktivite gösterirken bu etkinin yeşil çay içeren örneklerde daha fazla olduğu tespit edilmiştir. Yeşil çay ekstraktı ilave edilen örnekler siyah çay ekstraktı içerenler ile kıyaslandıklarında depolama boyunca daha yüksek DPPH radikalini bağlama aktivitesi göstermişlerdir. Yeşil çay, içilebilir yoğurt örneklerinin toplam fenolik miktarları açısından siyah çaya göre daha üstün bir etki göstermiştir. Anahtar Kelimeler: Çay; İçilebilir yoğurt; Antimikrobiyal; Antioksidan; Canlılık 


\section{Introduction}

Tea (Camellia sinensis, family Theaceae) is commonly consumed worldwide having various health benefits and physiological functionalities, such as antioxidative, anticarcinogenic and antimicrobial effects (Michalczyk \& Zawiślak 2008; Archana \& Abraham 2011; Chan et al 2011). The most important bioactive substances responsible for these health effects present in tea are tea polyphenols. Among various activities of tea, antioxidant function is one of the most important activities and most frequently studied (Erol et al 2009; Chan et al 2011). Different types of tea have been known to have good antioxidant activity whereas green tea has been reported to be the tea most abundant in catechins (Najgebauer-Lejko et al 2011).

The antimicrobial activity of tea which inhibit many undesired microbial growth are mainly related to their polyphenolic components (Michalczyk \& Zawiślak 2008). The extracts of Camellia sinensis have been determined to inhibit the growth of Staphylococcus aureus, Escherichia coli, Bacillus subtilis, Candida albicans and Bacillus cereus in many studies (Archana \& Abraham 2011; Chan et al 2011; Kumar et al 2012).

In recent years, green and black teas had been used because of their benefits to human health and their popular consumption worldwide in some dairy products such as milk, yoghurt, fermented milk and some other probiotic dairy products (Jaziri et al 2009; Najgebauer-Lejko et al 2011; Marhamatizadeh et al 2013; Ye et al 2013; Najgebauer-Lejko 2014). However, the effect of tea on the characteristics of drinking yoghurt has not been studied.

The objective of this study was to investigate the viability of yoghurt starter bacteria (Streptococcus thermophilus and Lactobacillus bulgaricus), antimicrobial and antioxidant properties in presence of green and black teas during refrigerated storage. In addition, two different ratios $(2 \%$ or $4 \%)$ were applied in order to state the effect of tea on the properties of drinking yoghurt is dose-dependent or not.

\section{Material and Methods}

\subsection{Material}

UHT milk which was used in the manufacture of drinking yoghurt was obtained from Pinar Dairy Products, Izmir, Turkey. Green and black tea leaves were obtained from a national commercial brand (Caykur, Rize, Turkey). Yoghurt starter culture, a combination of $S$. thermophilus and $L$. delbrueckii subsp. bulgaricus obtained in freeze-dried form (Jointec 12) from CSL (Centro Sperimentale del Latte, Italy) company.

Folin-Ciocalteu's phenol reagent was purchased from Merck (Darmstadt, Germany). Trolox (6-hydroxy-2,5,7,8-tetramethylchroman-2-carboxylic acid, Cat: 23,881-3), DPPH (2,2-diphenyl-1picrylhydrazyl, D-9132) and gallic acid (G-7384) were purchased from Sigma-Aldrich (Steinheim, Germany). All other reagents and solvents commercially obtained were of analytical grade. All spectrophotometric data were acquired using a Cary 50 Scan UV-Visible spectrophotometer (UK).

\subsection{Drinking yoghurt manufacture}

The freeze dried culture was propagated by inoculating in skim milk which was heated at $90{ }^{\circ} \mathrm{C}$ for $30 \mathrm{~min}$ before the inoculation. The inoculated milk was incubated at $45^{\circ} \mathrm{C}$ until $\mathrm{pH} 4.6$ was reached, then stored overnight at $40^{\circ} \mathrm{C}$ in refrigerator.

The whole milk was heated to $85{ }^{\circ} \mathrm{C}$ and waited for $10 \mathrm{~min}$, then divided into five lots and supplemented with 2\% black tea (2BDY), $4 \%$ black tea (4BDY), $2 \%$ green tea (2GDY) or $4 \%$ green tea (4GDY). On the other hand, the control drinking yoghurt did not contain any tea extract (CDY). The teas were infused for 10 min then different batches were filtered through sterile cotton to remove the particles. The milk samples were then cooled to 45 ${ }^{\circ} \mathrm{C}$ and inoculated 3\% yoghurt culture and divided into $200 \mathrm{~mL}$ plastic containers and incubated at 42 ${ }^{\circ} \mathrm{C}$ until a pH 4.6 was reached. After fermentation, the samples were cooled and stored at $4{ }^{\circ} \mathrm{C}$ for 21 days for the analyses. 


\section{3. $p H$}

The $\mathrm{pH}$ value of drinking yoghurt samples was determined using a $\mathrm{pH}$ meter (Hanna Instruments Model pH: 211; Woonsocket, RI, USA). pH values were determined during 21 days of storage.

\subsection{Microbiological analyses}

S. thermophilus enumeration was performed on M17 agar and aerobically at $37^{\circ} \mathrm{C}$ for $48 \mathrm{~h}$ whereas the counts of $L$. bulgaricus were detected on MRS agar and at microaerophilic conditions at $42{ }^{\circ} \mathrm{C}$ for $72 \mathrm{~h}$ using the pour plate technique (Jaziri et al 2009).

\subsection{Antimicrobial activity}

\subsubsection{Bacterial strains}

The studied microbial strains were Bacillus cereus (from Collection Española de Cultivas Tipo CECT 495), Escherichia coli, Staphylococcus aureus and Candida albicans (from American Type Culture Collection; ATCC 29252, ATCC 29213, ATCC 64550 , respectively).

\subsubsection{Antimicrobial activity analysis}

Antibacterial susceptibility testing was done by using disc diffusion method (Radji et al 2013). The microorganisms were activated by inoculating a loopful of the strain in the Tripton Soy Broth and incubated at $37{ }^{\circ} \mathrm{C}$ for one night. Then $0.2 \mathrm{~mL}$ of inoculum size was used $10^{8}$ cells as per McFarland Standard. Then Tripton Soy Agar was poured into Petri Plates. For agar disc diffusion technique, the test compound $(0.2 \mathrm{~mL})$ was introduced on the disc $(0.7 \mathrm{~cm})(\mathrm{Hi}$ media) and then allowed to dry. The plates were incubated at $37^{\circ} \mathrm{C}$ for $24 \mathrm{~h}$. Microbial growth was determined by measuring the diameter of zone of inhibition. The experiment was done three times and the mean values are presented.

\subsection{Antioxidant activity and total phenolic content (TPC)}

The DPPH radical scavenging activity of the samples was estimated according to the procedure described by Unal \& Akalın (2012). Trolox was used as a reference antioxidant at a concentration of $0.25 \mathrm{mg} \mathrm{mL}^{-1}$. DPPH scavenging activity percent was calculated by Equation 1.

DPPH scavenging activity $(\%)=[$ (control absorbanceextract absorbance)/(control absorbance)]x100

TPC of each sample was determined according to Folin-Ciocalteu method (Singleton \& Rossi 1965; Singleton et al 1999). The phenolic content was compared to a gallic acid standard curve and the total phenolic content of the samples was expressed as milligrams gallic acid equivalents (GAE) per liter of sample. The equation for the gallic acid calibration curve was $y=0.0012 x+0.0359$ and the correlation coefficient was $\mathrm{R}^{2}=0.9983$.

\subsection{Statistical analysis}

The experiments were performed in twice with three parallel. Six values for each sample were averaged $(n=6)$. The data obtained was processed by one-way ANOVA using the general linear model procedure of the SPSS version 11.05 (SPSS Inc., Chicago, IL, USA). The means were compared with the Duncan test at $\mathrm{P}<0.05$ level.

\section{Results and Discussion}

\subsection{Changes in $p H$ values}

The changes in the $\mathrm{pH}$ values of drinking yoghurt samples during refrigerated storage are shown in Figure 1. The $\mathrm{pH}$ values of control drinking yoghurt (CDY) and sample with $4 \%$ green tea (4GDY) decreased at the end of the storage period $(\mathrm{P}<0.05)$. Similar results were obtained for control ayran (Turkish drinking yoghurt) and yoghurt supplemented with tea throughout the storage by other studies (Najgebauer-Lejko et al 2011; Marhamatizadeh et al 2013; Erkaya et al 2015).

The lowest $\mathrm{pH}$ values were detected in control sample during storage whereas samples supplemented with green tea generally had higher $(\mathrm{P}<0.05)$ values. Najgebauer-Lejko (2014) also determined higher $\mathrm{pH}$ values in acidophilus milk with $5 \%$ green tea infusion than that of plain acidophilus milk during 21 days of storage. In addition, parallel to our results the authors concluded that the $\mathrm{pH}$ of 


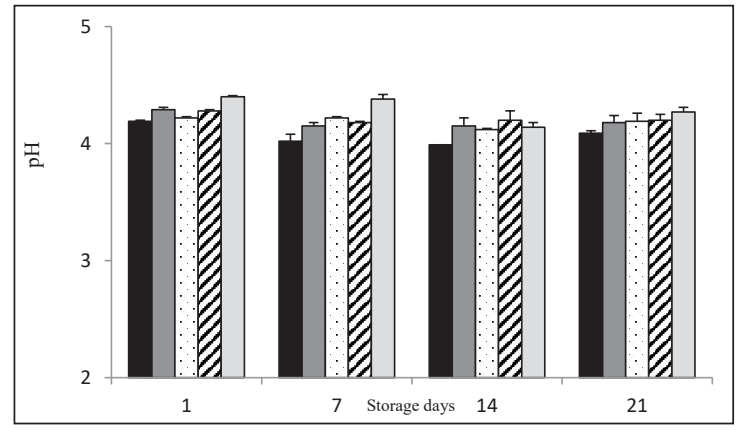

Figure 1- Changes in pH during 21 days of storage in drinking yoghurt samples; CDY, control drinking yoghurt (black bar); 2BDY, drinking yoghurt supplemented with $2 \%$ black tea (dark gray bar); 4BDY, drinking yoghurt supplemented with $4 \%$ black tea (dotted bar); 2GDY, drinking yoghurt supplemented with $2 \%$ green tea (hashed bar); 4GDY, drinking yoghurt supplemented with $4 \%$ green tea (light gray bar)

acidophilus milk was higher for higher levels of green tea supplementation, which was accompanied by the lower values of titratable acidity. In contrast, the $\mathrm{pH}$ value of yoghurt with $5 \%$ green tea infusion was found significantly lower than that of control yoghurt (without tea infusion) in another study (Najgebauer-Lejko et al 2011). Najgebauer-Lejko et al (2014) also detected higher titratable acidity in $5 \%$ supplemented yoghurt than that of plain yoghurt. This can be caused by the higher ratio of green tea when compared to the ratio used in our study.

\subsection{Viability of Streptococcus thermophilus and Lactobacillus bulgaricus}

The changes in the viable counts of $S$. thermophilus and L. bulgaricus in drinking yoghurts during refrigerated storage are presented in Table 1 . The samples supplemented with $2 \%$ either green or black tea had higher $(\mathrm{P}<0.05)$ viable counts of both starter bacteria than those of infused by the ratio of $4 \%$, in storage days which significant differences were observed.

The highest $(\mathrm{P}<0.05)$ viable counts of $S$. thermophilus were enumerated in control sample on the $1^{\text {st }}$ and $14^{\text {th }}$ day whereas there were no significant differences between all samples on the other days

Table 1- Changes in the viable counts of $S$. thermophilus and $L$. bulgaricus during refrigerated storage of drinking yoghurts (log efu $\left.\mathrm{g}^{-1}\right)$

\begin{tabular}{lcccc}
\hline \multirow{2}{*}{$\begin{array}{l}\text { Drinking } \\
\text { yoghurt } \\
\text { type }^{I}\end{array}$} & \multicolumn{4}{c}{ Storage day } \\
\cline { 2 - 5 } & \multicolumn{4}{c}{ S. thermophilus } \\
CDY & $8.83 \pm 0.01^{\mathrm{Aa}}$ & $8.58 \pm 0.03^{\mathrm{Ab}}$ & $7.83 \pm 0.02^{\mathrm{Ac}}$ & $7.41 \pm 0.06^{\mathrm{Ad}}$ \\
2BDY & $8.75 \pm 0.02^{\mathrm{Ba}}$ & $8.41 \pm 0.65^{\mathrm{Aa}}$ & $7.62 \pm 0.03^{\mathrm{Ba}}$ & $7.39 \pm 0.72^{\mathrm{Aa}}$ \\
4BDY & $8.67 \pm 0.04^{\mathrm{Ca}}$ & $7.91 \pm 0.01^{\mathrm{Ab}}$ & $7.51 \pm 0.03^{\mathrm{Cc}}$ & $6.82 \pm 0.01^{\mathrm{Ad}}$ \\
2GDY & $8.70 \pm 0.00^{\mathrm{BCa}}$ & $7.79 \pm 0.21^{\mathrm{Ab}}$ & $7.54 \pm 0.00^{\mathrm{Cb}}$ & $6.86 \pm 0.01^{\mathrm{Ac}}$ \\
4GDY & $8.55 \pm 0.03^{\mathrm{Da}}$ & $7.86 \pm 0.01^{\mathrm{Ab}}$ & $7.38 \pm 0.01^{\mathrm{Dc}}$ & $6.73 \pm 0.03^{\mathrm{Ad}}$ \\
& & $L$. bulgaricus & \\
CDY & $8.84 \pm 0.01^{\mathrm{Aa}}$ & $8.65 \pm 0.01^{\mathrm{Ab}}$ & $7.85 \pm 0.01^{\mathrm{Ac}}$ & $7.46 \pm 0.01^{\mathrm{Ad}}$ \\
2BDY & $8.76 \pm 0.02^{\mathrm{Ba}}$ & $8.48 \pm 0.04^{\mathrm{Bb}}$ & $7.64 \pm 0.08^{\mathrm{ABc}}$ & $6.91 \pm 0.01^{\mathrm{Ad}}$ \\
4BDY & $8.64 \pm 0.04^{\mathrm{Ca}}$ & $7.96 \pm 0.01^{\mathrm{Cb}}$ & $7.48 \pm 0.21^{\mathrm{ABc}}$ & $6.80 \pm 0.04^{\mathrm{Ad}}$ \\
2GDY & $8.74 \pm 0.01^{\mathrm{Ba}}$ & $8.45 \pm 0.04^{\mathrm{Ba}}$ & $7.59 \pm 0.13^{\mathrm{ABa}}$ & $8.38 \pm 2.09^{\mathrm{Aa}}$ \\
4GDY & $8.62 \pm 0.01^{\mathrm{Ca}}$ & $7.95 \pm 0.01^{\mathrm{Cb}}$ & $7.25 \pm 0.40^{\mathrm{Bc}}$ & $6.74 \pm 0.03^{\mathrm{Ac}}$ \\
\hline
\end{tabular}

${ }^{1} \mathrm{CDY}$, control drinking yoghurt; 2BDY, drinking yoghurt supplemented with $2 \%$ black tea; 4BDY, drinking yoghurt supplemented with $4 \%$ black tea; 2 GDY, drinking yoghurt supplemented with $2 \%$ green tea; 4GDY, drinking yoghurt supplemented with $4 \%$ green tea; ${ }^{\text {a-d }}$, means \pm standard deviations in the same row with different superscript lowercase letters are significantly different $(P<0.05)$; ${ }^{A-D}$, means \pm standard deviations in the same column with different superscript uppercase letters are significantly different $(\mathrm{P}<0.05)$ 
of storage. The control samples showed the highest viability of $L$. bulgaricus on $1^{\text {st }}$ and $7^{\text {th }}$ day whereas there were no significant differences between all samples at the end of the storage. It can be concluded that addition of tea to drinking yoghurt did not increase the growth and survival of both yoghurt starter bacteria during storage. Jaziri et al (2009) also reported that green or black tea extract fortification has no effect on the development of either S. thermophilus or L. bulgaricus in yoghurt that can be caused by insignificant changes in acid development. Similar to our results, NajgebauerLejko et al (2011) enumerated lower viable counts of both S. thermophilus and L. bulgaricus in yoghurt supplemented with $5 \%$ green tea when compared to control yoghurt without tea infusion. In contrast, enhancing effect of green tea addition on the viability of probiotic bacteria such as L. casei,
L. acidophilus and B. bifidum was observed in another study (Marhamatizadeh et al 2013).

The viability of yoghurt bacteria in drinking yoghurt samples supplemented with tea extracts did not significantly $(\mathrm{P}>0.05)$ changed at the end of the storage when compared to the beginning of the period. Although some fluctuations were observed in streptococci counts, Najgebauer-Lejko (2014) also could not determine any significant change in acidophilus milk infused by $5 \%$ green tea within 21 days of storage period.

\subsection{Antimicrobial activity}

It was found that tea extracts have antimicrobial effect on E.coli, B. cereus, S. aureus and C. albicans at both $2 \%$ and $4 \%$ ratios however this effect was detected higher in samples containing green tea extracts (Table 2). Michalczyk \& Zawiślak (2008)

Table 2- Antimicrobial activity of drinking yoghurt samples during storage given as the diameter of inhibited zone (mm)

\begin{tabular}{lcrrrr}
\hline & & \multicolumn{4}{c}{ Bacterial strains } \\
\cline { 2 - 5 } Product $^{1}$ & Storage days & E. coli & B. cereus & S. aureus & C. albicans \\
\hline CDY & 1 & $3.10 \pm 0.11$ & $4.35 \pm 0.17$ & $2.75 \pm 0.29$ & $3.30 \pm 0.34$ \\
& 7 & $2.35 \pm 0.24$ & $4.20 \pm 0.22$ & nzd & $4.20 \pm 0.21$ \\
2BDY & 14 & $1.83 \pm 0.24$ & $2.12 \pm 0.09$ & nzd & $2.55 \pm 0.06$ \\
& 21 & nzd & $0.37 \pm 0.75$ & nzd & $2.10 \pm 0.20$ \\
& 1 & $4.92 \pm 0.09$ & $6.33 \pm 0.22$ & $7.90 \pm 0.27$ & $10.62 \pm 0.12$ \\
& 7 & $6.45 \pm 0.06$ & $5.45 \pm 0.31$ & $6.50 \pm 0.26$ & $6.67 \pm 0.15$ \\
4BDY & 14 & $5.50 \pm 0.09$ & $7.25 \pm 0.19$ & $5.25 \pm 0.10$ & $8.25 \pm 0.25$ \\
& 21 & $3.25 \pm 0.29$ & $5.22 \pm 0.20$ & $4.87 \pm 0.12$ & $7.42 \pm 0.28$ \\
& 1 & $9.22 \pm 0.20$ & $9.22 \pm 0.20$ & $11.72 \pm 0.09$ & $12.50 \pm 0.08$ \\
2GDY & 7 & $7.97 \pm 0.17$ & $8.67 \pm 0.09$ & $9.82 \pm 0.05$ & $9.72 \pm 0.12$ \\
& 14 & $6.36 \pm 0.15$ & $7.35 \pm 0.19$ & $8.15 \pm 0.19$ & $10.40 \pm 0.16$ \\
& 21 & $4.32 \pm 0.15$ & $5.27 \pm 0.22$ & $5.75 \pm 0.29$ & $9.17 \pm 0.20$ \\
& 1 & $8.02 \pm 0.26$ & $8.20 \pm 0.20$ & $9.27 \pm 0.32$ & $12.25 \pm 0.30$ \\
& 7 & $6.10 \pm 0.11$ & $7.65 \pm 0.17$ & $8.20 \pm 0.16$ & $11.25 \pm 0.35$ \\
& 14 & $6.37 \pm 0.26$ & $6.55 \pm 0.07$ & $7.55 \pm 0.05$ & $9.27 \pm 0.32$ \\
& 21 & $3.80 \pm 0.24$ & $4.10 \pm 0.10$ & $6.27 \pm 0.25$ & $7.62 \pm 0.09$ \\
& 1 & $11.55 \pm 0.34$ & $12.75 \pm 0.64$ & $13.20 \pm 0.19$ & $15.60 \pm 0.43$ \\
& 7 & $9.30 \pm 0.26$ & $11.37 \pm 0.32$ & $12.60 \pm 0.08$ & $13.55 \pm 0.05$ \\
& 14 & $8.45 \pm 0.24$ & $9.37 \pm 0.25$ & $10.65 \pm 0.30$ & $12.27 \pm 0.32$ \\
& 21 & $5.37 \pm 0.20$ & $8.00 \pm 0.00$ & $7.95 \pm 0.05$ & $9.85 \pm 0.19$ \\
\hline
\end{tabular}

${ }^{1} \mathrm{CDY}$, control drinking yoghurt; 2BDY, drinking yoghurt supplemented with $\%$ black tea; 4BDY, drinking yoghurt supplemented with $4 \%$ black tea; $2 \mathrm{GDY}$, drinking yoghurt supplemented with $2 \%$ green tea; $4 \mathrm{GDY}$, drinking yoghurt supplemented with $4 \%$ green tea; nzd, no zone detected 
and Chan et al (2011) reported that green tea extract inhibited various Gram positive bacteria but $S$. aureus was the least susceptible. Kumar et al (2012) also investigated the antibacterial activity of green tea leaves against environmental sources originated S. aureus, Streptococcus, Pseudomonas aeruginosa, Bacillus, E.coli and Proteus species and detected significant activity.

In addition, antimicrobial activity showed reduction during the whole storage period. Increase in the ratio of green tea extract used also cause an enhancement in the antimicrobial activity of the samples. Drinking yoghurt samples supplemented by black tea extract also show antimicrobial activity against $C$. albicans but lower than green tea extract in our study. Similarly, Chou et al (1999) detected a lower antimicrobial activity against B. subtilis, E. coli, S. aureus, Salmonella sp. and Proteus vulgaris in black tea extract when compared to green tea extract. Archana \& Abraham (2011) also reported that E. coli, Enterococccus faecalis, S. aureus, Pseudomonas aeruginosa and C. albicans were very sensitive to fresh green tea extracts.

Wu et al (2007) found that water extracts of various tea types including green tea showed an antimicrobial activity against $S$. aureus and B. subtilis at $2 \mathrm{mg} \mathrm{mL}^{-1}$ concentration, however no antimicrobial effect was observed on Gram (-) E. coli. On the other hand, some other authors have reported that the level of resistance of Gram (-) bacteria against the extracts were related to the lipopolysaccharides in the cell membrane and the antimicrobial activity was higher in fresh tea leaves due to their high polyphenol content (Chou et al 1999; Alzoreky \& Nakahara 2003; Chan et al 2011).

\subsection{DPPH radical scavenging activity}

The DPPH scavenging activity of the drinking yoghurt samples ranged from $76.42 \%$ to $96.21 \%$ (Figure 2). Trolox at a concentration of $0.25 \mathrm{mg}$ $\mathrm{mL}^{-1}$ showed a DPPH scavenging activity of 97.04\%. McCue \& Shetty (2005) also investigated the DPPH scavenging activity of soy yoghurt produced by kefir cultures and reported the activity as $92.3 \%$ after $48 \mathrm{~h}$ of production which is similar to our results obtained on the $1^{\text {st }}$ day of storage. Unal \& Akalın (2012) and Unal et al (2013) also determined the DPPH scavenging activity as approximately $90 \%$ in control yoghurt samples at the beginning of the refrigerated storage. Moreover, Farvin et al (2010) studied the antioxidant activity of different fractions of yoghurt and found the DDPH radical scavenging activity of crude yoghurt $\left(0.2 \mathrm{mg} \mathrm{mL}^{-1}\right)$ to be $94.47 \%$.

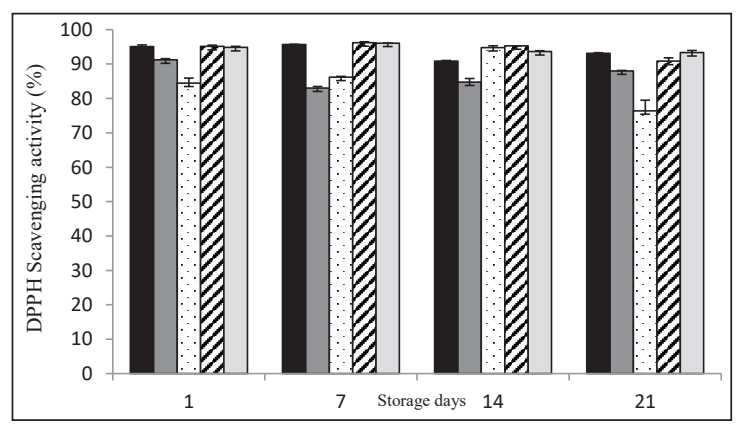

Figure 2- DPPH scavenging activity (\%) of drinking yoghurt samples during 21 days of storage at 4 ${ }^{\circ} \mathrm{C}$; CDY, control drinking yoghurt (black bar); 2BDY, drinking yoghurt supplemented with $2 \%$ black tea (dark gray bar); 4BDY, drinking yoghurt supplemented with $4 \%$ black tea (dotted bar); 2GDY, drinking yoghurt supplemented with $2 \%$ green tea (hashed bar); 4GDY, drinking yoghurt supplemented with $4 \%$ green tea (light gray bar)

The drinking yoghurt samples infused by green tea extract had the highest $(\mathrm{P}<0.05)$ scavenging activity when compared to those supplemented with black tea extract throughout the storage. This shows the superiority of green tea in terms of radical scavenging activity which can be attributed to containing higher amount of total phenolic content (Michalczyk \& Zawiślak 2008; Jaziri et al 2009; Chan et al 2011). Similarly, Najgebauer-Lejko et al (2011) determined a higher anti radical power in yoghurt with $5 \%$ green tea infusion when compared to natural yoghurt. In another study, a higher DPPH radical scavenging activity (9-29 fold) was detected in fermented milks infused by $5 \%, 10 \%$ 
and $15 \%$ green tea than fermented milk without any supplementation (Najgebauer-Lejko 2014).

The scavenging activity of all samples showed a fluctuation throughout the storage period and the activity significantly decreased $(\mathrm{P}<0.05)$ at the end of the storage according to the beginning of the period. The reduction in the activity has been attributed to the ability of starter bacteria (especially lactobacilli) to utilize phenolic components by producing phytase enzyme (Subrota et al 2013). In our study, similar fluctuation was observed in the viability of L. bulgaricus during 21 days of storage. On the other hand, synergistic effect of phenolic compounds with each other or other compounds can result an enhancement of antioxidant activity within such a fluctuation (Shahidi et al 1994).

\subsection{Total phenolic content (TPC)}

TPC of drinking yoghurt samples changed in an order of $\mathrm{CDY}<2 \mathrm{BDY}<4 \mathrm{BDY}<2 \mathrm{GDY}<4 \mathrm{GDY}$ during whole storage period (Figure 3 ). This order showed that the type of tea and the infusion ratio were found statistically significant. Green tea infusion increased the total phenolic content of samples more than those supplemented with black tea. This is probably because green tea includes higher amount of both catechin and other phenolic compounds than black tea as reported by many researchers (Jaziri et al 2009; Chan et al 2011). Similarly, Komes et al (2007) investigated polyphenol content of some types of tea and reported that green tea is the richest source of unmodified polyphenols among all types of tea. On the other hand, the superiority effect of green tea on the phenolic content of samples can be attributed to the relationship between tea polyphenols and milk. Ye et al (2013) investigated the interactions of black tea polyphenols (BTP) and green tea polyphenols (GTP) with milk. The researchers reported that the interactions between individual catechins (e.g. (-)-epigallocatechin gallate, (-)-epigallocatechin and (-)-epicatechin gallate) and pure proteins (eg: $\beta$-casein, $\alpha$-casein and $\beta$-lactoglobulin) or milk proteins occurred with the formation of catechin-protein complexes. They concluded that the structures of catechins affect the affinities of tea catechins for casein micelles in the GTP-milk system but no obvious impact for the BTP-milk system.

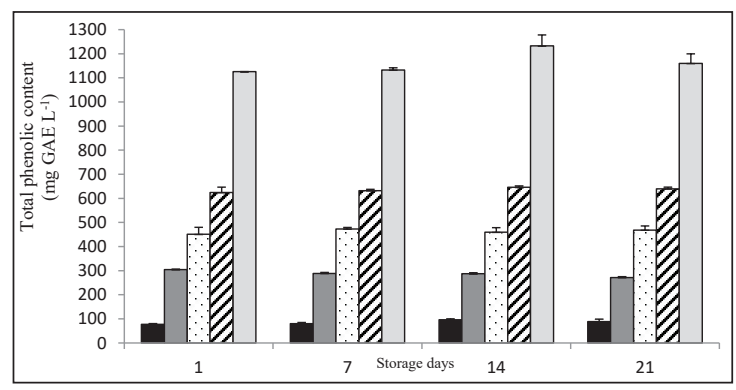

Figure 3- Total phenolic content (mg GAE $\left.\mathrm{L}^{-1}\right)$ of drinking yoghurt samples during 21 days of storage at $4{ }^{\circ} \mathrm{C}$; CDY, control drinking yoghurt (black bar); 2BDY, drinking yoghurt supplemented with $2 \%$ black tea (dark gray bar); 4BDY, drinking yoghurt supplemented with $4 \%$ black tea (dotted bar); 2GDY, drinking yoghurt supplemented with $2 \%$ green tea (hashed bar); 4GDY, drinking yoghurt supplemented with $4 \%$ green tea (light gray bar)

The superiority of green tea infusion on the TPC of the samples is in parallel to those of DPPH scavenging activity. This can be supported by the findings of Erol et al (2009) that the authors found a correlation between TPC and antioxidant activity of some types of tea.

The TPC of drinking yoghurt samples infused by tea extract did not generally changed $(\mathrm{P}>0.05)$ throughout the storage period. This can be caused by the ability of yoghurt starter bacteria to preserve the catechins from oxidation during both yoghurt fermentation and storage (Kachouri \& Hamdi 2006).

\section{Conclusions}

The present study indicated that, addition of tea to drinking yoghurt did not increase the survival of both yoghurt starter bacteria probably due to the changes in $\mathrm{pH}$ values throughout the storage. On the other hand, green tea improves both antimicrobial and antioxidant activities of drinking yoghurt higher than black tea. This effect was stronger when the 
supplementation ratio increased from $2 \%$ to $4 \%$. Therefore, fortification of drinking yoghurt with green tea can be an alternative pathway to create a functional dairy product having both nutritional and health benefits. Furthermore, sensory and physical quality characteristics should be also evaluated before marketing such a product.

\section{Acknowledgements}

The authors thank Ege University Scientific Research Project Council for the financial support for this research (project no: 2011-ZRF-012).

\section{References}

Alzoreky N S \& Nakahara K (2003). Antibacterial activity of extracts from edible plants commonly consumed in Asia. International Journal of Food Microbiology $\mathbf{8 0}$ : 223-230

Archana A \& Abraham J (2011). Comparative analysis of antimicrobial activity of leaf extracts from fresh green tea, commercial green tea and black tea on pathogens. Journal of Applied Pharmaceutical Science 1(8): 149152

Chan E W C, Soh E Y, Tie P P \& Law Y P (2011). Antioxidant and antibacterial properties of green, black, and herbal teas of Camellia sinensis. Pharmacognosy Research 3(4): 266-272

Chou C C, Lin L L \& Chung K T (1999). Antimicrobial activity of tea as affected by the degree of fermentation and manufacturing season. International Journal Food Microbiology 48: 125-130

Erkaya T, Başlar M, Şengül M \& Ertugay M F (2015). Effect of thermosonication on physicochemical, microbiological and sensorial characteristics of ayran during storage. Ultrasonics Sonochemistry 23: 406412

Erol N T, Sarı F, Polat G \& Velioglu Y S (2009). Antioxidant and antibacterial activities of various extracts and fractions of fresh tea leaves and green tea. Tarim Bilimleri Dergisi-Journal of Agricultural Sciences 15(4): 371-378

Farvin K H S, Baron C P, Nielsen N S \& Jacobsen C (2010). Antioxidant activity of yoghurt peptides: Part 1 -in vitro assays and evaluation in $\omega-3$ enriched milk. Food Chemistry 123: 1081-1089
Jaziri I, Slama M B, Mhadhbi H, Urdaci M \& Hamdi M (2009). Effect of green black teas (Camellia sinensis L.) on the characteristic microflora of yogurt during fermentation and refrigerated storage. Food Chemistry 112: 614-620

Kachouri F \& Hamdi M (2006). Use of Lactobacillus plantarum in olive oil process and improvement of phenolic compounds content. Journal of Food Engineering 77: 746-752

Komes D, Kartović D, Kovačević Ganič K, Horžić D \& Glavaš I (2007). Effect of various extraction conditions on the phenols content and free radical scavenging activity of tea. In: E S Lazos (Ed), Proceedings of the $5^{\text {th }}$ International Congress on Food Technology, 9-11 March, Solun, Greece, pp. 83-87

Kumar A, Kumar A, Thakur P, Patil S, Payal C, Kumar A \& Sharma P (2012). Antibacterial activity of green tea (Camellia sinensis) extracts against various bacteria isolated from environmental sources. Recent Research in Science and Technology 4(1): 19-23

Marhamatizadeh M H, Ehsandoost E \& Gholami P (2013). The influence of green tea (Camellia sinensis L.) extract on characteristic of probiotic bacteria in milk and yoghurt during fermentation and refrigerated storage. International Journal of Farming and Allied Sciences 2(17): 599-606

McCue P P \& Shetty K (2005). Phenolic antioxidant mobilization during yogurt production from soy milk using kefir cultures. Process Biochemistry 40: 17911797

Michalczyk M \& Zawiślak A (2008). The effect of tea infusions on the proliferation of selected bacteria important for the human intestinal tract. Acta Scientiarum Polonorum Technologia Alimentaria 7(1): 59-65

Najgebauer-Lejko D (2014). Effect of green tea supplementation on the microbiological, antioxidant, and sensory properties of probiotic milks. Dairy Science and Technology 94: 327-339

Najgebauer-Lejko D, Sady M, Grega T \& Walczycka M (2011). The impact of tea supplementation on microflora, $\mathrm{pH}$ and antioxidant capacity of yoghurt. International Dairy Journal 21: 568-574

Najgebauer-Lejko D, Zmudzinski D, Ptaszek A \& Socha R (2014). Textural properties of yogurts with green tea and pu-erh tea additive. International Journal of Food Science and Technology 49: 1149-1158 
Radji M, Agustama R A, Elya B \& Tjampakasari C R (2013). Antimicrobial activity of green tea extract against isolates of methicillin-resistant Staphylococcus aureus and multi-drug resistant Pseudomonas aeruginosa. Asian Pasific Journal of Tropical Biomedicine 3(8): 663-667

Shahidi F, Wanasundara U N \& Amarowicz R (1994). Natural antioxidants from low-pungency mustard flour. Food Research International 27: 489-493

Singleton V \& Rossi J A (1965). Colorimetry of total phenolics with phosphomolybdic-phosphotungistic acid reagents. American Journal of Enology and Viticulture 16: 144-158

Singleton V L, Orthofer R \& Raventos-Lamuela R M (1999). Analysis of total phenols and other oxidation substrates and antioxidants by means of folinciocalteu reagent. Methods in Enzymology 299: 152178

Subrota H, Shilpa V, Brij S, Vandna K \& Surajit M (2013). Antioxidative activity and polyphenol content in fermented soy milk supplemented with WPC-70 by probiotic Lactobacilli. International Food Research Journal 20(5): 2125-2131

Unal G \& Akalın A S (2012). Antioxidant and angiotensinconverting enzyme inhibitory activity of yoghurt fortified with sodium calcium caseinate or whey protein concentrate. Dairy Science and Technology 92(6): 627-639

Unal G, El S N, Akalın A S \& Dinkçi N (2013). Antioxidant activity of probiotic yoghurt fortified with milk protein based ingredients. Italian Journal of Food Science 25(1): 63-69

Wu S C, Yen G C, Wang B S, Chiu C K, Yen W I, Chang L W \& Duh P D (2007). Antimutagenic and antimicrobial activities of pu-erh tea. LWT-Food Science and Technology 40(3): 506-512

Ye J, Fan F X X \& Liang Y (2013). Interactions of black and green tea polyphenols with whole milk. Food Research International 53: 449-455 